\title{
外付け門形鉄骨による既存 RC 造建築物の耐震補強工法に関する実験的研究 EXPERIMENTAL STUDY OF AN INNOVATIVE R/C BUILDING REINFORCEMENT METHOD UTILIZING STEEL PORTAL FRAMES
}

\author{
阪口暁洋*1, 倉重正義*2, 古川忠稔*3, 村田義行*4 \\ 植木 理枝子*5, 坪崎裕 幸*6, 塩 見勝 信*7, 今井克 彦*8 \\ Akihiro SAKAGUCHI, Masayoshi KURASHIGE, Tadatoshi FURUKAWA, Yoshiyuki MURATA, \\ Rieko UEKI, Hiroyuki TSUBOSAKI, Katsunobu SHIOMI and Katsuhiko IMAI
}

\begin{abstract}
There exist in Japan a large number of old $\mathrm{R} / \mathrm{C}$ buildings requiring reinforcement against the possible destructive effects of seismic activity. Responding to this, the authors of this paper propose an innovative reinforcing method that utilizes steel portal frames: the Portal-Grid Method. Based on the fact that for steel the modulus of elasticity and yield strength are respectively approximately 10 times and $20-25$ times that of concrete, it is posited that steel portal frames - smaller in size than the respective R/C sections - are able to provide sufficient rigidity and strength to reinforce relatively weak R/C frames without braces. The steel portal frames - connected to exterior of R/C buildings - are composed of reinforcing $\mathrm{H}$-sections whose rigidity can be adjusted to that required for complementing the respective $\mathrm{R} / \mathrm{C}$ sections. In the process of their research, the authors have experimentally proved that the Portal-Grid Method suitably improves the strength of R/C frames that the strength and rigidity of the reinforced frames can be calculated by summing up the strength and rigidity of the steel portal frames together with that of the $\mathrm{R} / \mathrm{C}$ frames.
\end{abstract}

Keywords: Existing R/C building, Seismic reinforcement, Steel portal frame, Built-up H-section, Rigidity, Exterior reinforcement 既存 $\mathrm{RC}$ 建築物，耐震補強，門形鉄骨，溶接 $\mathrm{H}$ 形鋼，剛性，外付補強

\section{1. 研究の背景と目的}

我国では、耐震設計基準を満たさない多くの RC 造建築物が見られ、 その耐震性が大きな問題となっている。1995 年の兵庫県南部地震では、 これらの RC 造建築物に甚大な被害があった。1995 年 12 月の门耐震改 修促進法」の施行以来、耐震改修の事例は増加傾向にあるが、遅々と して進んでいないのが現状である。

また、耐震補強工法も数多く開発されているが、これまでの工法は、 不足している耐震性を向上させることに重点を置いた構造補強工法 がほとんどである。この様な耐震補強工法の中で、鉄骨を用いた工法 は、その多くがブレース材を用いる工法が前提となっている。初期の 鉄骨ブレース工法は、壁面内に $\mathrm{H}$ 形鋼ブレースを配置したものであっ た。 $\mathrm{H}$ 形鋼ブレース工法は、大断面 $\mathrm{H}$ 形龬や座屈止めを用いるため、 外観や室内からの景観を大きく損なうといった視覚的な問題が生じ た。近年では、外付け鉄骨ブレースや座屈拘束ブレースなどの開発に より(1-6)、施工性や構造性能が格段に向上するとともに細く軽快なブ レースの適用例も增加している。しかしながら建物の使用上支障とな るブレースを省略するといった工法の開発には至っていないのが現

状である。

本論文では、ブレース材を用いない新たな概念の鉄骨補強工法とし て、外付け門形鉄骨補強工法(ポータル・グリッド工法、以下 PG 工法 と呼ぶ)の実験を行ったので報告する(図 1 参照)。本工法は、既存 RC 柱及び $\mathrm{RC}$ 梁と同等の曲げ剛性を持つ溶接 $\mathrm{H}$ 形鋼によって構成された 門形鉄骨を既存躯体外周部の構造部材外側に取り付けることにより 補強を行うものである。本研究は、鋼材と耐震補強する既存躯体のコ ンクリートのヤング保数比が 10 程度であることに着目し、既存 RC 断 面よりも小さな溶接 $\mathrm{H}$ 形鋼断面でも同等の曲げ剛性と数倍の曲げ降 伏耐力を付加することが可能であると着想したことが、発端となうて いる。

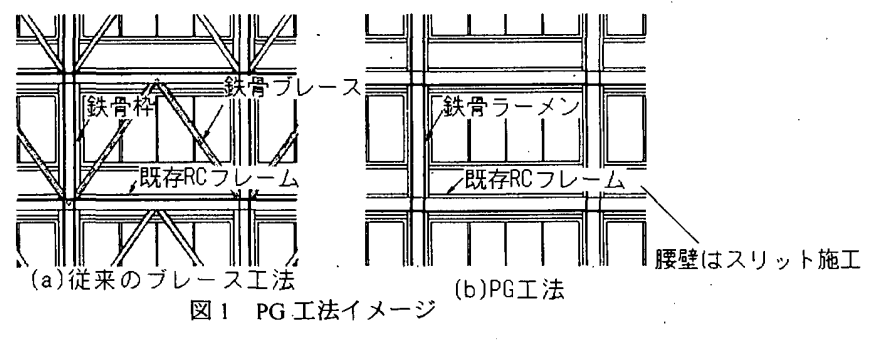

*1 五洋建設(侏) 工修

*2 高周波熱錬(姝) 部唇

*3 大阪大学大学院工学研究科地球総合工学専攻 学内講師・工博

*4 高周波熱錬(侏) 工博

*5 大阪大学大学院工学研究科地球総合工学専攻 大学院生

*6 五洋建設(侏) 部長

*7 部佥

*8 大阪大学大学院工学研究科地球総合工学尃攻 教授・迌博
Penta-Ocean Construction Co., Ltd, M. Eng.

General Manager, Netsuren Co., Ltd.

Assist. Prof., Dept. of Global Architecture, Osaka Univ., Dr. Eng.

Netsuren Co., Ltd., Dr. Eng.

Grad. Student, Dept. of Global Architecture, Osaka Univ.

General Manager, Penta-Ocean Construction Co., Ltd.

General Manager, Kanayama-Komuten Co., Ltd.

Prof., Dept. of Global Architecture, Osaka Univ., Dr. Eng. 
従来の鉄骨外付け工法で用いられる鉄骨枠はブレースを取り付ける ための補助材であるが、本工法では鉄骨ラーメンの剛性及び耐力を積 極的に利用することを特徵としている。既存躯体と補強門形鉄骨の一 体化は、既存躯体に打設したあと施工アンカー、門形鉄骨に溶接した スタッド、スパイラル筋、無収縮モルタルによって行う(図 2 参照)。

本論文では、PG 工法の補強有効性を検証するために行った 1 層 1 スパン RC 門形試験体の絽返し載荷実験について述べる。本研究の目 的は、補強後の門形試験体の荷重変形関係が RC 骨組と門形鉄骨柱部 分の予測値を単純加算することによって求められることを検証する ことである。

\section{2. 実験計画 \\ 2-1 試験体}

試験体は、5 6 階建て RC 造建物の 1 階曲げ降伏型柱を想定した約 1/3 スケールの RC 門形試験体(No.1)とそれを門形鉄骨で補強した試験 体 3 体の合計 4 体である。階高 $3 \mathrm{~m}$,スパン 5 6m 程度を想定している。 尚、腰壁、垂壁付きの極短柱は対象としない。試験体は床スラブによ る横拘束を想定して、倒れ止め梁に取り付けた治具により補強鉄骨と 反対側のコンクリート接合部パネルソーンで面外にのみ拘束されて いる。門形鉄骨はスタッド、あと施エアンカー及び充填モルタルによ って接合されている。RC 骨組と接合されているので座屈防止は施し ていない。 RC 骨組に加えられた水平力は、上部梁部分の頭付きス夕 ッドとあと施エアンカーによって門形鉄骨にも移行するよう計画し た。これはブレース付き外付け鉄骨と同様の考え方である。

実験変数は門形鉄骨柱の曲け剛性とし、No.2 は曲け剛性が RC 門形 試験体柱の初期ひび割れ後と同等曲げ剛性(初期剛性の $70 \%$ と仮定)を 持つ溶接 $\mathrm{H}$ 形鋼により補強したもの、No.3,4 はそれぞれ 75\%,50\%程 度の曲け㴊性を持つ溶接 $\mathrm{H}$ 形鋼により補強したものである。図 3 に試 験体を示す。鉄骨柱下端と土台は連続していない。図 4 にNo.2 4 の 柱及び梁断面図を、図 5 にあと施工アンカー・頭付きスタッドを示す。 表 1 には、各試験体柱部分の溶接 $\mathrm{H}$ 形鋼の断面諸量を示す。接合部パ ネルソーンは柱、梁ウェブと同厚である。

コンクリートのヤング係数を $E_{c}=21 \mathrm{kN} / \mathrm{mm}^{2}$ と仮定すると、 RC 柱(柱 $\square-200 \times 200$ )の曲げ風性は、

$E_{c} \cdot I_{r}=2.79 \times 10^{9}\left(\mathrm{kN} \cdot \mathrm{mm}^{2}\right)$

である。

\begin{tabular}{|r|r|r|r|r|r|r|}
\hline $\begin{array}{c}\text { 試験体 } \\
\text { No }\end{array}$ & $\begin{array}{c}\mathrm{H} \\
(\mathrm{mm})\end{array}$ & $\begin{array}{c}\mathrm{b} \\
(\mathrm{mm})\end{array}$ & $\begin{array}{c}\mathrm{t}_{\mathrm{f}} \\
(\mathrm{mm})\end{array}$ & $\begin{array}{c}\mathrm{t}_{\mathrm{w}} \\
(\mathrm{mm})\end{array}$ & $\begin{array}{c}\text { Is } \\
\left(\mathrm{mm} \mathrm{m}^{4}\right)\end{array}$ & $\begin{array}{c}\mathrm{EI}\left(\mathrm{kN} \cdot \mathrm{mm}^{2}\right) \\
\times \mathrm{E}=205\left(\mathrm{kN} / \mathrm{mm}^{2}\right)\end{array}$ \\
\hline \hline 2 & 145 & 80 & 12 & 6 & $9.40 \times 10^{6}$ & $1.97 \times 10^{9}$ \\
\hline 3 & 145 & 80 & 9 & 4.5 & $7.44 \times 10^{6}$ & $1.56 \times 10^{9}$ \\
\hline 4 & 145 & 80 & 4.5 & 4.5 & $4.50 \times 10^{6}$ & $0.94 \times 10^{9}$ \\
\hline
\end{tabular}

$$
\text { 既存RC柱 }
$$

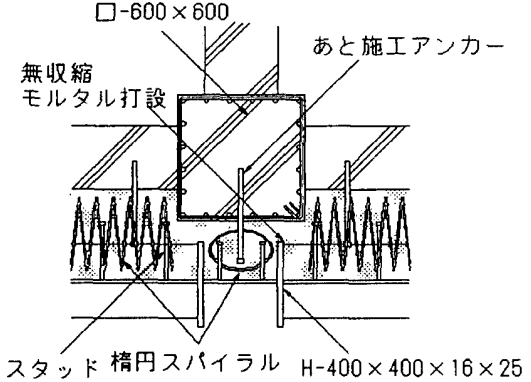

図 2 PG 工法柱断面例

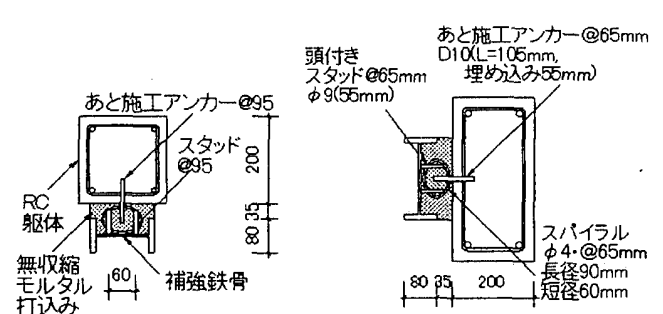

図 4 試験体柱及び梁断面図
載荷時には初期ひび割れの影響を考慮して曲げ剛性が $70 \%$ 程度に低 下すると仮定した。従って、RC 柱の初期ひび割れ後の曲け剛性は

$E \cdot I=E_{c} \cdot I_{r c} \times 0.7=1.96 \times 10^{9}\left(\mathrm{kN} \cdot \mathrm{mm}^{2}\right)$

となる。門形鉄骨の曲け䦌性は、この値を基にして決定した。

$\mathrm{RC}$ 骨組と門形鉄骨の間接接合部のあと施工アンカー及び頭付きス タッドは文献(7)によって設計した。アンカー及びスタッドは、試験体 No.2 の鉄骨柱終局層せん断力を伝達できる本数の 1.5 倍程度を梁に配 置した。柱には、鉄骨終局層せん断力時の梁せん断力を伝達できる本 数を配置した。あと施工アンカーの有効埋め込み長さは、 $55 \mathrm{~mm}$ とし、 梁、柱それぞれ 65、95mm 間隔で打設した。頭付きスタッドは、 $\phi 9$ で $55 \mathrm{~mm}$ のものをアンカーと同じ間隔で $\mathrm{H}$ 形鋼ウェブに溶接した。ス タッドは JIS B1198 に準じて特別に製作した。スパイラル筋は $\phi 4$ 直 径 $75 \mathrm{~mm}$ の円形スパイラルを押しつぶして成形し、長径 $90 \mathrm{~mm}$ 、短径 60mmのものを製作した。

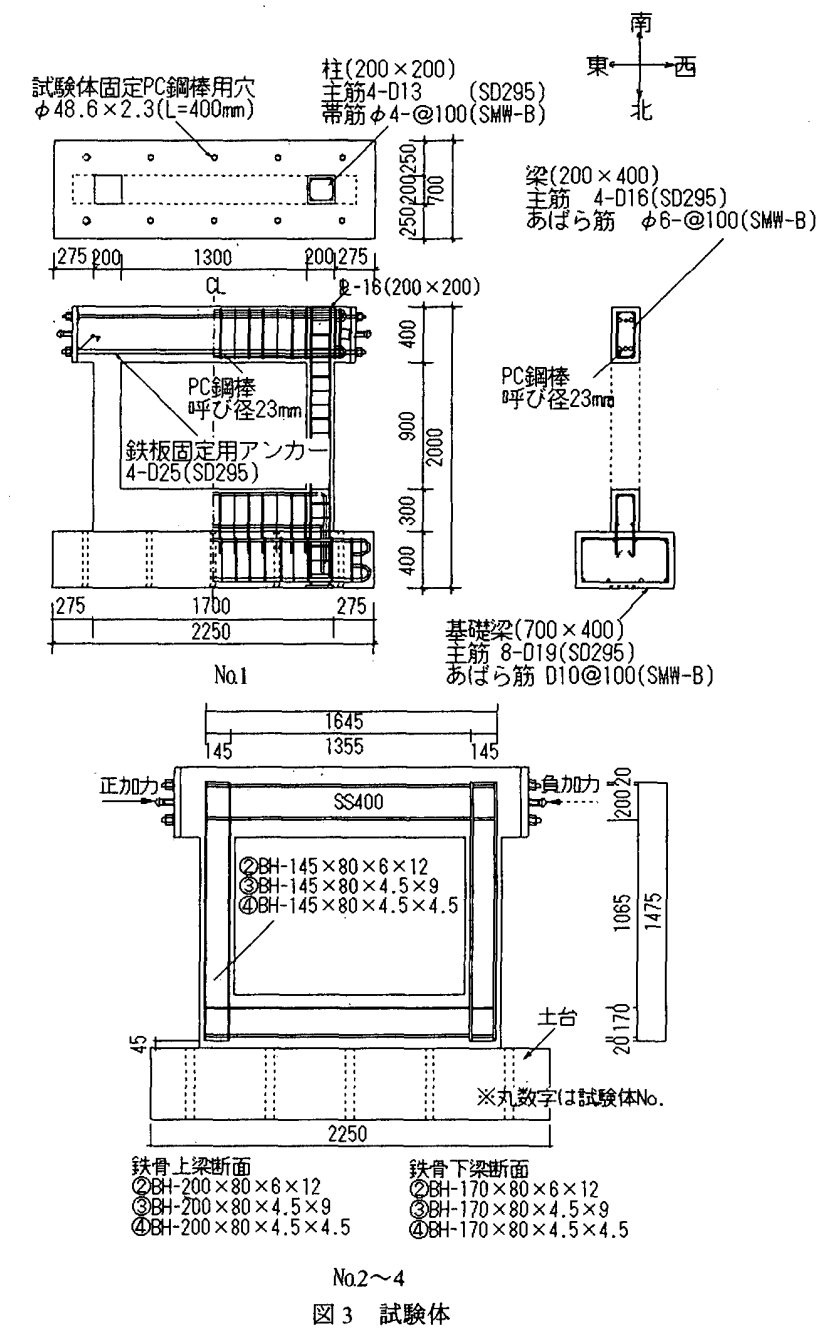

図 3 試験体

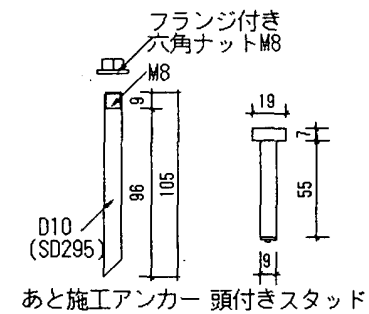

図 5 アンカーとスタッド 


\section{2-2 載荷方法}

載荷は、図 6 のようなパンタグラフ型載荷試験装置を用いて、一定 軸圧縮力下における両側押しによる繰返し載荷を行った。水平力の導 入は $500 k N$ オイルジャッキによって水平加力用フレームを水平移動さ せて行う。図 7 に示すように上梁両端の鋼板に高力ボルトを取り付け ボルト頭を押すことにより水平荷重を作用させる機構としている。柱 1 本あたりの導入軸力は、1 階柱の軸力を想定しコンクリート調合強 度 $21 \mathrm{~N} / \mathrm{mm}^{2}$ の $20 \%$ にあたる $168 \mathrm{kN}$ とし、2000kN オイルジャッキを用 いて加力梁を介して導入した。軸力を導入する際、試験装置の自重が 作用しないように調整している。
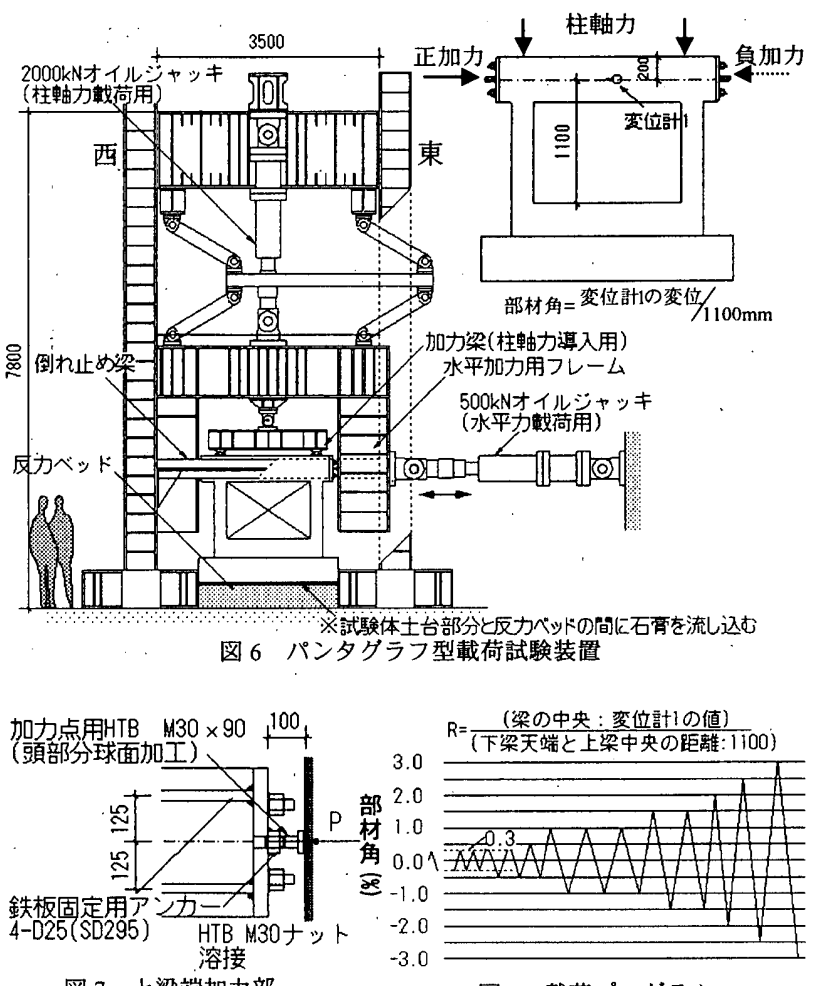

図 7 上梁端加力部

図 8 載荷プログラム

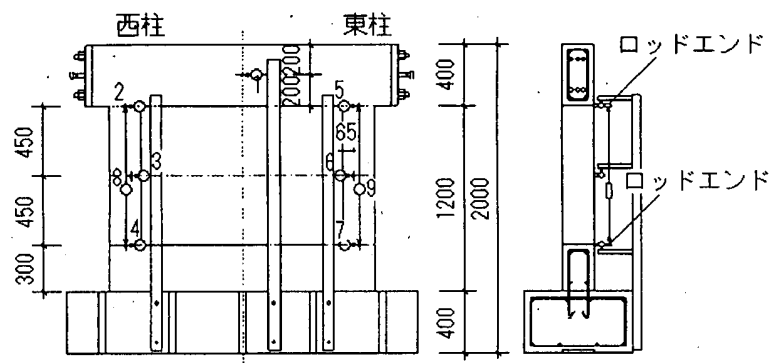

図 9 変位計設置状況
水平載荷は、柱の初期導入軸力を保持した状態で図 8 に示す載荷プ ログラムに基づいて繰返す計画とした。尚、部材角は試験体上梁中央 部に設けた変位計 1 の值を試験体下梁の天端から上梁の中央部までの

高さ $1100 \mathrm{~mm}$ で除したものである。

\section{2-3 変位計、歪ゲージの設置位置}

試験体には、変位と歪を測定するため、変位計と歪ゲージを取り付 けた。図 9 に変位計の設置位置、図 10 に歪ゲージの貼付位置を示す。 歪ゲージは、東側柱に貼付した。また、 $\mathrm{RC}$ 柱主筋にも、柱付根部(下 梁天端)から上側 $20 \mathrm{~mm}$ の位置に歪ゲージを貼付した。

\section{3. 実験結果及び考察}

3-1 材料実験結果

試験体に用いた材料試験結果を表 2 に示す。

コンクリート材料試験は、実験日に併せて材齢 46 日,50日,53 日で実 験を行った。また、モルタルの材料試験も実験日に併せて行ったが、 材齢は 25 日,29 日,32 日であった。コンクリート及びモルタルの任縮 強度とヤング係数は、各材路に大きなばらつきが見られなかったため、 以後の検討には平均値を用いる。

\section{3-2 柱軸力導入時の鉄骨柱の応力度}

PG 工法では、既存 RC 骨組に補強鉄骨を取り付けるため、実際の 施工においては、鉄骨柱に軸力は作用しない。しかし、本実験では、 試験体製作の関係から柱軸力導入に先行して門形鉄骨を取り付けた ため、軸力導入時にある程度の軸力が鉄骨柱にも作用する。従って、 軸力導入時に鉄骨柱が負担する軸力量を確認することが必要である。

表 2 材料試験結果

(a) コンクリート (設計基準強度 $18 \mathrm{~N} / \mathrm{mm}^{2}$ )

(b) モルタル

\begin{tabular}{|c|c|c|c|c|c|}
\hline \multicolumn{3}{|c|}{ (設計基準強度 $18 \mathrm{~N} / \mathrm{mm}^{2}$ ) } & \multicolumn{3}{|c|}{ (設計基準強度 $36 \mathrm{~N} / \mathrm{mm}^{2}$ ) } \\
\hline 材齢 & $\begin{array}{l}\text { 圧縮強度 } \\
\left(\mathrm{N} / \mathrm{mm}^{2}\right)\end{array}$ & $\begin{array}{l}\text { ヤング係数 } \\
\left(\mathrm{kN} / \mathrm{mm}^{2}\right)\end{array}$ & 材齢 & $\begin{array}{l}\text { 圧縮強度 } \\
\left(\mathrm{N} / \mathrm{mm}^{2}\right)\end{array}$ & $\begin{array}{l}\text { ヤング係数 } \\
\left(\mathrm{kN} / \mathrm{mm}^{2}\right)\end{array}$ \\
\hline 百 & 25.7 & 22.9 & 25日 & 63.7 & 23.3 \\
\hline 日 & 26.2 & $\overline{22.5}$ & $\bar{日}$ & 70.4 & - \\
\hline 3日 & 26.8 & 22.5 & 32日 & 62.6 & 24.1 \\
\hline$\overline{\bar{F}}$ & 26.2 & 22.7 & 平均 & 65.6 & 23.7 \\
\hline
\end{tabular}

$$
\text { (c) 鋼材 }
$$

\begin{tabular}{|c|c|c|c|c|}
\hline & $\begin{array}{c}\text { 降伏応力度 } \\
\left(\mathrm{N} / \mathrm{mm}^{2}\right)\end{array}$ & $\begin{array}{c}\text { 最大応力度 } \\
\left(\mathrm{N} / \mathrm{mm}^{3}{ }^{3}\right.\end{array}$ & \begin{tabular}{|l|} 
ヤング係数 \\
$\left(\mathrm{kN} / \mathrm{mm}^{2}\right)$
\end{tabular} & $\begin{array}{c}\text { 破断伸び } \\
(\%)\end{array}$ \\
\hline 主筋(D13) & 350 & 487 & 187 & - \\
\hline 带荕 $(\phi 4)$ & 688 & 692 & 247 & - \\
\hline 門形鉄骨 $(t=12)$ & 295 & 433 & 206 & 42.1 \\
\hline 門形鉄骨 $(t=9)$ & 289 & 419 & 206 & 42.7 \\
\hline 門形鉄骨 $(t=6)$ & 248 & 334 & 206 & 49.9 \\
\hline 門形鉄骨 $(t=4.5)$ & 291 & 367 & 210 & 44.6 \\
\hline 頭付スタッド( $\phi 9)$ & 366 & 460 & 272 & - \\
\hline あと施エアンカー(D10) & 330 & 457 & 180 & 26 \\
\hline スパイラル笳 $(\phi 4)$ & 513 & 548 & 190 & - \\
\hline
\end{tabular}
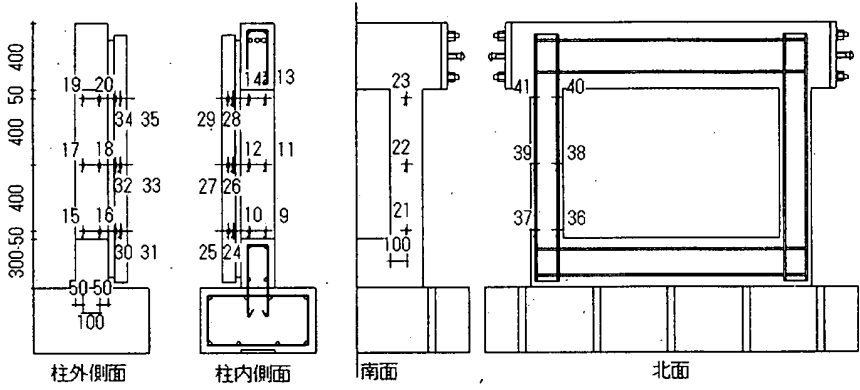

(b) 試験体 No.2 4 
応力度は軸力導入後、鉄骨に貼付した歪ゲージの平均歪の值をもと に算定した。軸力導入時の鉄骨柱フランジの応力度とフランジの降伏 応力度とを比較したものを表 3 に示す。鉄骨柱に作用する応力度は、 No.2 で降伏応力度の 1\%程度、No.3,4 で 3\%程度であった。応力度は上 部から下部に向かって若干大きくなる傾向にある。上記の初期軸力に よる影響は、後述する荷重変形関係の推定における全塑性モーメント の算定時に考慮する。

尚、軸力導入時に RC 骨組と鉄骨の接合部でのひび割れやずれは認 められなかった。

表 3 初期軸力によって門形鉄骨が受ける応力度

\begin{tabular}{|c|c|c|c|c|c|c|c|}
\hline \multirow[b]{2}{*}{$\begin{array}{c}\text { 試験 } \\
\text { 体 }\end{array}$} & \multicolumn{2}{|c|}{ 門型鉄骨下部 } & \multicolumn{2}{|c|}{ 門型鉄骨中部 } & \multicolumn{2}{|c|}{ 門型鉄骨上部 } & \multirow[b]{2}{*}{$\begin{array}{c}\text { フランジ } \\
\text { 降伏 } \\
\text { 応カ度 } \\
\left(\mathrm{N} / \mathrm{mm}^{2}\right)\end{array}$} \\
\hline & $\begin{array}{c}\text { 軸力 } \\
\text { 導入時 } \\
\text { 応力度 } \\
\left(\mathrm{N} / \mathrm{mm}^{2}\right)\end{array}$ & $\begin{array}{l}\text { 応力 } \\
\text { 度比 } \\
(\%)\end{array}$ & $\begin{array}{c}\text { 軸力 } \\
\text { 導入時 } \\
\text { 応力度 } \\
\left(\mathrm{N} / \mathrm{mm}^{2}\right)\end{array}$ & $\begin{array}{l}\text { 応力 } \\
\text { 度比 } \\
(\%)\end{array}$ & $\begin{array}{c}\text { 軸力 } \\
\text { 導入時 } \\
\text { 応力度 } \\
\left(\mathrm{N} / \mathrm{mm}^{2}\right)\end{array}$ & $\begin{array}{l}\text { 応力 } \\
\text { 度比 } \\
(\%)\end{array}$ & \\
\hline jo. 1 & - & $=$ & - & - & - & - & - \\
\hline No.2 & 3.96 & 1. & 3.12 & $\overline{1.0}$ & 2.1 & 0 . & 94.7 \\
\hline No.3 & 9.34 & 3.23 & 9.27 & 3. & 8.83 & 3. & 288.8 \\
\hline No.4 & 9.92 & 3.41 & 9.76 & 3.35 & 7.47 & 2.57 & 291.0 \\
\hline
\end{tabular}

※応力度比=軸力導入時応力度/フランジ降伏応力度

\section{3-3 破壊性状及び荷重・変形関係}

破壊に至る経緯を表 4 に、荷重変形関係を図 11 に示す。また、写 真 1 に破壊時の状況を示す。No.1 では、写真(a)に示す様に柱脚部のせ ん断破壊が顕著になり急激に耐力が低下した。No.2 4 は、写真(b) (d) のように絽返し載荷に伴う X 形のひび割れが進行し、破壊した。

本実験では加力心と試験体の剛心がずれているが、図 6 に示す治具 による横拘束が充分であったため、㨝れの影響と見られる変形や破壊 は認められなかった。

図 12 にNo.1 とNo.2 の部材角 $1.0 \%, 2.0 \%$ 時のひび割れ状況を示す。 門形鉄骨によって補強を行った No.2 4 の最大荷重は No.1(無補強)の 最大荷重の 2 2.5 倍程度まで上昇した。図 11 には、RC 柱脚せん断破 壊点(○印)と最終サイクルを示す。無補強試験体 No.1 は RC 柱の主筋 が降伏した後、部材角士 $2 \%$ までほぼ一定の荷重を維持する曲げ破壊モ ードを示した。最終サイクル(部材角 $2.5 \%$ )時には、柱脚部でせん断破 壊し、酎力が急激に低下した。No.2 4 は、No.1 が一定荷重を維持し ている最大部材角 $\pm 2 \%$ で最大荷重に達し、その後 $\mathrm{RC}$ 柱上下端での曲 げひび割れ挔大とともに徐々に耐力が低下した。最終サイクル(部材角 $3.0 \%)$ で急激に耐力が低下することはなく、繰返し加力下でも安定 した挙動を示した。No.2〜No.4 は、No.1 に比べ、耐力・剛性が大幅 に上昇すること及び $\mathrm{RC}$ 柱が耐力消失後もかなりの耐力を維持してい ることから上梁部分で鉄骨へ応力移行していることがわかる。

No.1 と No.2 のひび割れ状況を比較すると、部材角 $1.0 \%$ 時では $2 つ$ の試験体の間に大きな差は見られなかった。部材角 $2.0 \%$ 時では、No.1 の方が No.2 よりも柱頭部のひび割れが広範囲に広がっている。また、 柱脚部ではNo.1 のほうが No.2 よりも大きなせん断ひび割れが観測で きた。門形鉄骨で補強した他の 2 体についても同様の傾向が見られた。

各試験体の曲げひび割れを比較すると、同程度の部材角において初 期ひび割れが目視できたが、初期ひび割れ発生時の荷重は、No.2 4 の方が No.1 よりも 1.5〜2 倍程度大きい。また、RC 柱の主筋降伏時の 部材角は、No.2から No.4にかけて徐々に小さくなっている。No.1'と No.4 の主筋は同程度の変形下で降伏している。No.2 4 の降伏時の荷 重は No.1の 1.8 2.7 倍程度と大幅に上昇している。門形鉄骨の降伏開

始時の部材角は、No.2 から No.4にかけて小さくなっている。また、 試験体 No.1 のせん断ひび割れ荷重は約 $104 k N$ で、後に示す(4)式の予 測値ともほぼ一致している。

表 4 実験経過一覧

\begin{tabular}{|c|c|c|c|c|c|c|c|c|}
\hline \multirow{3}{*}{$\begin{array}{c}\text { 試験体 } \\
\text { No }\end{array}$} & \multicolumn{2}{|c|}{$\begin{array}{c}\text { RC曲げひひ割れ } \\
\text { 荷重 } \\
\end{array}$} & \multirow{2}{*}{\multicolumn{2}{|c|}{$\frac{\mathrm{RC} \text { 主筋降伏荷重 }}{}$}} & \multicolumn{2}{|c|}{$\begin{array}{c}\text { 鉄骨柱 } \\
\text { 降伏荷重" }\end{array}$} & \multicolumn{2}{|c|}{ 最大水平荷重 } \\
\hline & \multirow[b]{2}{*}{$\begin{array}{c}\text { 部材角 } \\
(\text { () }\end{array}$} & \multirow[b]{2}{*}{$\begin{array}{c}\text { 水平 } \\
\text { 荷重 } \\
(\mathrm{kN})\end{array}$} & & & \multirow[b]{2}{*}{$\begin{array}{c}\text { 部材角 } \\
(\text { () }\end{array}$} & \multirow[b]{2}{*}{$\begin{array}{l}\text { 水平 } \\
\text { 荷重 } \\
(\mathrm{kN})\end{array}$} & \multirow[b]{2}{*}{$\begin{array}{c}\text { 部材角 } \\
(\text { (x) }\end{array}$} & \multirow[b]{2}{*}{$\begin{array}{l}\text { 水平 } \\
\text { 荷重 } \\
(\mathrm{kN})\end{array}$} \\
\hline & & & $\begin{array}{c}\text { 部材角 } \\
(\%)\end{array}$ & $\begin{array}{l}\text { 水平 } \\
\text { 荷重 } \\
\text { (kN) }\end{array}$ & & & & \\
\hline No. 1 & 0.07 & 35.4 & -0.91 & -101 & - & - & 1.01 & 106 \\
\hline No. 2 & 0.13 & 71.2 & -1.51 & -270 & 1.15 & 235 & 2.02 & 265 \\
\hline No. 3 & 0.06 & 55.1 & -1.27 & -225 & 0.99 & 202 & 2.00 & 249 \\
\hline No. 4 & 0.10 & 59. 9 & -0.89 & -186 & 0.79 & 176 & 2.00 & 213 \\
\hline
\end{tabular}

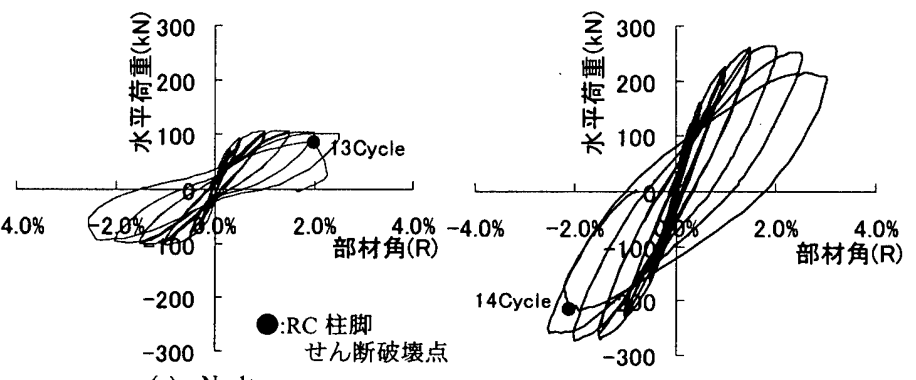

(a) No.1

$\widehat{z} 300$

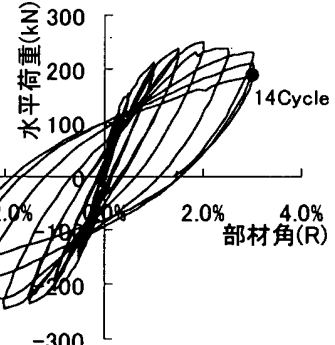

(c) No.3

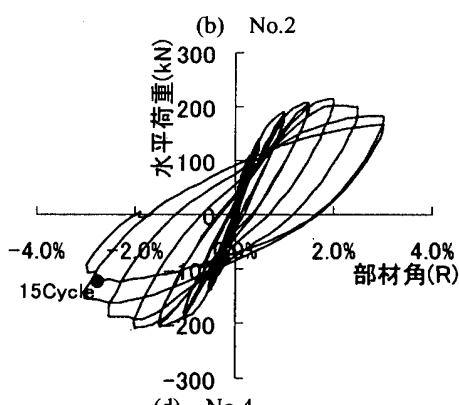

(d) No.4

図 11 試験体の荷重変形関係

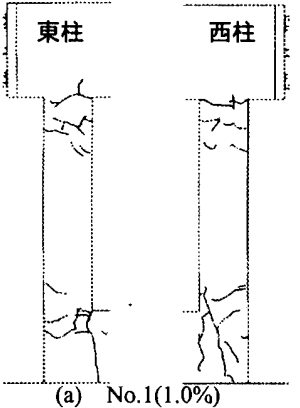

(a) No.1(1.

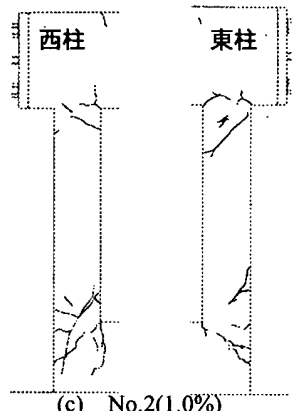

図 12 ひび割れ状況(No.1,2)

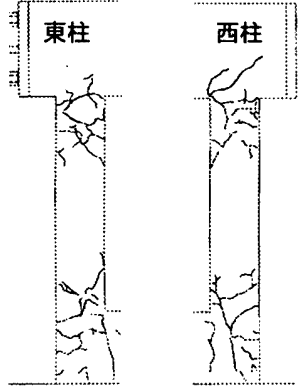

(b) No.1(2.0\%)

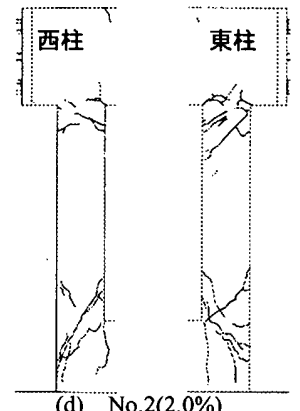

(d) No.2(2.0\%) 


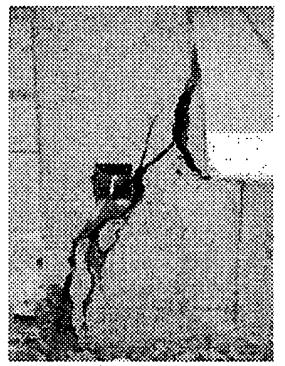

(a) No.1

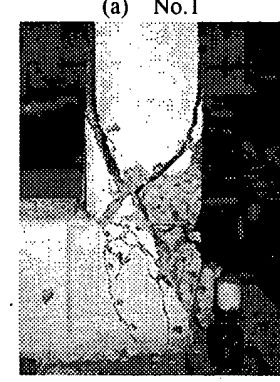

(c) No.3

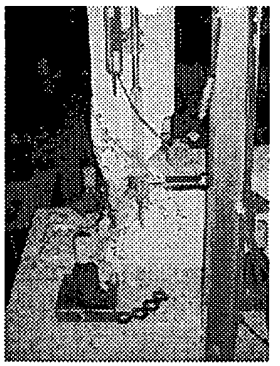

(b) No.2

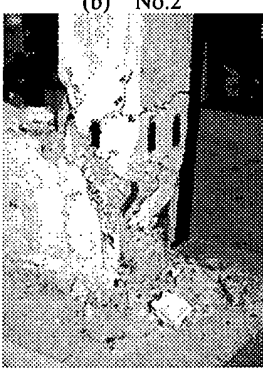

破填状況 (d) No.4

\section{3-4 門型鉄骨と RC 骨組の接合部}

補強試験体では、 RC 骨組と門形鉄骨の接合部に注入した無収縮モ ルタル面と RC 面の境界にひびが入り、荷重の増加と共に桩大したが、 大変形時にモルタル部が剥落することはなかった。No.2 では約 $220 \mathrm{kN}$ でひび割れが認められた。この荷重は、鉄骨柱の表 4 に示す降伏荷重 より若干低い值である。最終サイクルでは、柱脚部でモルタルの剥落 が生じたが、急激な耐力低下は見られなかった。

\section{3-5 荷重変形関係の推定}

補強後の荷重変形関保は、RC 骨組と門形鉄骨柱の予測值の単純和 によって推定する。荷重変形関係の推定は、以下の手順によって行っ た。材料の機械的性質は、表 2 によった。

(1) $\mathrm{RC}$ 骨組の荷重変形関係

$\mathrm{RC}$ 骨組の荷重変形関係は、以下のようにして求めた。尚、試 験体上梁と下梁は剛と仮定している。従って、柱のシアスパンは上下 梁の内面となる。

曲げひび割れモーメント $(M c)$ は、「鉄筋コンクリート構造計算規 準・同解説」 ${ }^{8}$ に示す(1)式によった。

$$
M_{c}=0.56 \sqrt{\sigma_{B}} \cdot Z_{e}+N D / 6
$$

$Z_{e}$ :断面係数 $N$ :軸力

曲げひび割れ時の転倒モーメントによる柱付加軸力は $\pm 13.9 \mathrm{kN}$ であ る。これを考慮した曲げひび割れモーメントは、 $10.4,9.5 \mathrm{kN} \cdot \mathrm{m}$ である が、差が小さいため推定値では平均値をとる。

従って、曲げひび割れモーメント時の荷重 $\left(Q_{M C}\right.$ : 左右柱の合計 $)$ は、 式となる。

$$
Q_{M C}=2 \times \frac{2 \times M_{c}}{h}(=44.3 \mathrm{kN})
$$

\section{$h:$ 上下梁内法距離}

柱のせん断ひび割れ耐力 $\left(Q_{c}\right)$ は、文献(8)に示す梁のせん断ひび割れ 耐力 ( $\left.Q_{c}\right)$ を与える(3)式に、軸力を考慮した項を加えて(4)式より求め た。(c $\left.Q_{c}\right)$ 尚、軸力の扱いは、文献(9)に示すプレストレストコンクリー 卜柱のせん断破壊耐力を与える式を参考にした。せん断ひび割れ時の
転倒モーメントによる柱付加軸力は $331.4 k N$ である。これを考慮した せん断ひび割れモーメントは、47.2, $46.1 \mathrm{kN} \cdot \mathrm{m}$ であるが、差が小さい ため推定值では平均值をとる。

$$
\begin{aligned}
& { }_{8} Q_{c}=2 \times A c \cdot \tau_{c}=2 A c \cdot \frac{0.085 k_{c}\left(500+\sigma_{B}\right)}{M / Q d+1.7} \\
& { }_{c} Q_{c}=2 \times A c \cdot \tau_{c}=2 A c \cdot \frac{0.085 k_{c}\left(500+\sigma_{B}+0.1 \sigma_{0}\right)}{M / Q d+1.7}(=104.7,102.6 \mathrm{kN})
\end{aligned}
$$

$A c$ :梁及び柱の全断面積 $k c$ :断面寸法による補正係数 $\sigma_{0}$ :柱軸方 向応力度

${ }_{c} Q_{c}$ による層せん断力は、水平力 $103.7 \mathrm{kN}$ に対応し、実験值ともほぼ一 致している。

終局曲げモーメント $\left(M_{u}\right)$ は、“「鉄筋コンクリート構造計算規準·同解 説,付録 20」 ${ }^{10}$ に示す(5)式によった。

$$
M_{u}=m \times a_{t} \times \sigma_{y} \times D+0.5 \times N \times D\left(1-\frac{N}{b D F_{c}}\right)
$$

$m:$ 柱主筋重心間距離／柱せい $a_{t}$ :引張鉄筇断面樻 $\sigma_{y}:$ 引張鉄筋降伏応力度

文献(2)では、通常の断面諸量を考慮して $m=0.8$ としているが、推定式 では本実験の試験体諸量を(5)の原式に代入し、 $m=0.65$ とした。終局 曲げモーメント時の転倒モーメントによる柱付加軸力は $\pm 37.3 \mathrm{kN}$ で ある。これを考虑した終局曲げモーメントは、試験体の左右柱でそれ ぞれ $28.1,23.4 \mathrm{kN} \cdot \mathrm{m}$ となる。

従って、柱曲げ終局強度は、(6)式となる。

$$
Q_{M u}=\frac{2\left({ }_{L} M_{u}+{ }_{r} M_{u}\right)}{h}(=114.5 \mathrm{kN})
$$

${ }_{L} M_{u}$ : 左柱の終局曲げモーメント ${ }_{R} M_{u}$ :右柱の終局曲げモーメント 柱のせん断終局耐力 $\left(Q_{s u}\right)$ は、文献 11 に示す(7)式によった。

$$
Q_{s u}=\left\{\frac{0.068 p_{t}^{0.23}\left(F_{c}+18\right)}{M /(Q d)+0.12}+0.85 \sqrt{p_{w} \cdot \sigma_{w y}}+0.1 \sigma_{0}\right\} b j
$$

$p_{i}$ :引張鉄筋比 $p_{w}:$ : せ断補強筋比 $\sigma_{w}$ : せん断補強筋降伏応力度 $\sigma_{0}:$ 柱軸方向応力度 $j:$ 応力中心間距離

せん断終局時の転倒モーメントによる柱付加軸力は $\pm 39.1 \mathrm{kN}$ である。 せん断終局耐力は、左右柱の応力再配分がないものとして小さい方の

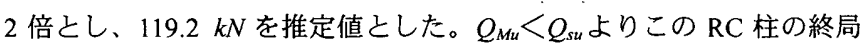

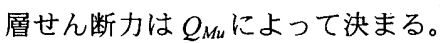

初期ひび割れ後の 2 次剛性を決める剛性低下率は、文献 12 に示す (8)式によった。転倒モーメントによる付加軸力は考慮していない。

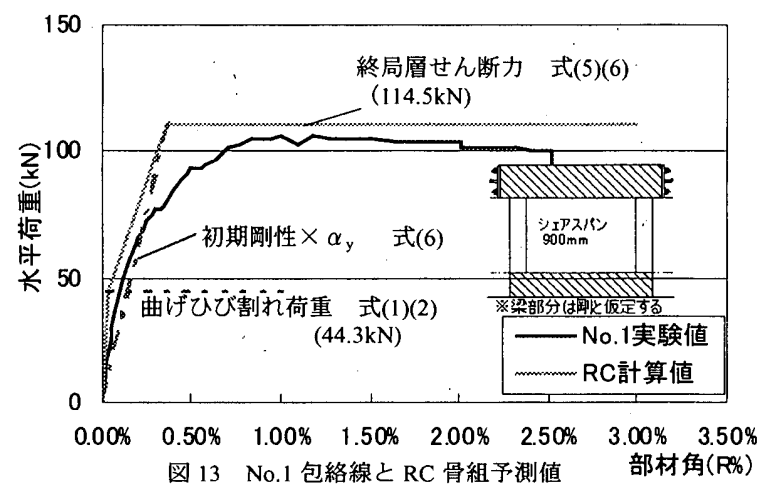


$\alpha_{y}=\left(0.043+1.64 n p_{t}+0.043 a / D+0.33 \eta_{0}\right)\left(\frac{d}{D}\right)^{2}(=0.261)$

$\eta_{0}=N / b D \sigma_{B} \quad n:$ ヤグ係数比 $a$ :シアスパン

$d:$ 曲げ材の圧縮縁から引張鉄筋重心までの距離

以上の諸量を用いて得られる荷重変形関倸を図 13 に示す。

(2)補強を行った試験体の予測值

補強試験体の荷重変形関係の予測值は、 $\mathrm{RC}$ 骨組の予測值と門形鉄 骨の予測值を単純に加算して求めた。尚、RC 骨組と門形鉄骨の一体 化部分に挿入したスパイラル筋と無収縮モルタルが、強度及び曲げ剛 性に与える影響は、荷重変形関係の推定には算入していない。 門形鉄骨の荷重変形関係は、材料試験結果から得られた門形鉄骨柱の 全塑性モーメント時の層せん断力とパネルゾーンのせん断降伏時の 水平荷重を算出し、小さいほうを最大層せん断力とした。尚、門形鉄 骨柱のシアスパンは、上梁の下端から下梁天端までの距離 $(h=1065 \mathrm{~mm})$ とした。また、門形鉄骨柱の変形は柱の曲け変形とパネルソーンのせ ん断変形による層間変位を加算して求めるものとする。

初期軸力による影響は、前述の結果に基づいて No.2 では門形鉄骨 柱部分の降伏軸力の $1.0 \%$ NNo.3,4では 3.0\%とじた。全塑性モーメン 卜算定時には、初期軸力と転倒モーメントによる柱付加軸力を考慮し ている。全塑性時の鉄骨柱断面応力度分布を図 14 に示す。これらの 軸力を考慮した鉄骨柱の全塑性曲げモーメントは No.2 で 42.4 , $42.9 \mathrm{kN} \cdot m$, No. 3 で $28.8,29.3 \mathrm{kN} \cdot \mathrm{m}$, No.4 で $27.3,27.6 \mathrm{kN} \cdot \mathrm{m}$ である。尚、 No.1 と同様に試験体上梁と下梁は、RC 骨組,門形鉄骨とも剛と仮定し ている。

柱全塑性モーメント時の門形鉄骨柱の層せん断力 $\left(Q_{M P C}\right)$ は、（9）式 となる(図 15 (a)参照)。

$Q_{M P C}=\frac{{ }_{u} M_{p c}+i M_{p c}}{h}$

${ }_{4} M p c,{ }_{1} M p c$ :柱全塑性モーメント(柱頭部,柱脚部)

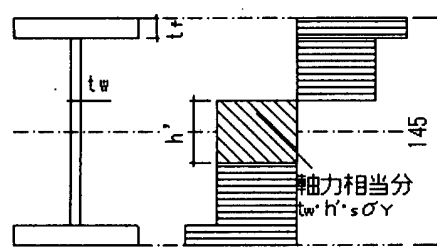

図 14 全塑性時柱断面応力度分布

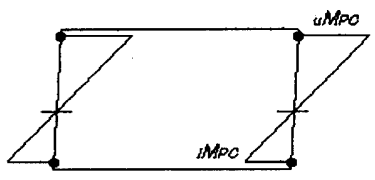

(a) 全望性乇ーメント時

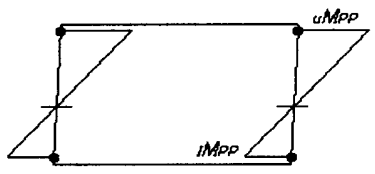

(b) パネルラ゙ーンせん断降伏時 図 15 鉄骨曲げモーメント図

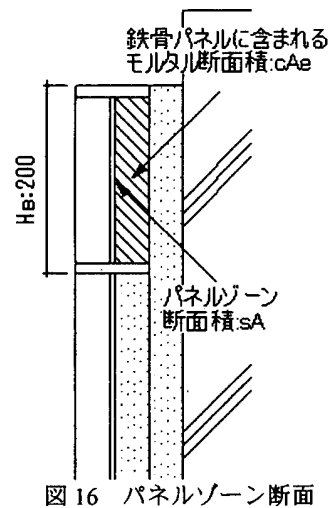

図 16 パネルソーン断面

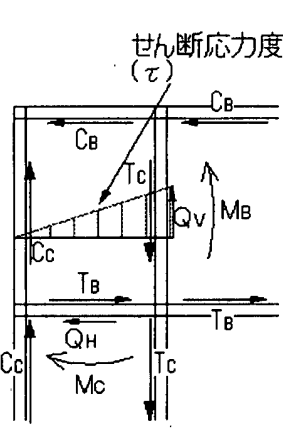

パネルせん断変形による層間変位

$$
\text { パネルせん断変形による層間変位 }
$$

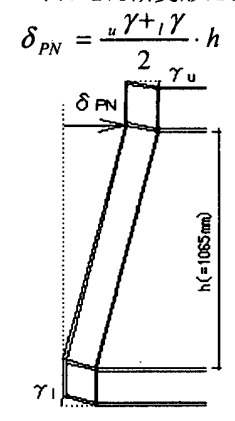

図 17 パネルソーンに作用するせん断力
パネルソーンのせん断降伏耐力 $\left(Q_{P P}\right)$ は、「鉄骨鉄筋コンクリート 構造計算規準」14.15)に示す(10)式によった。

$$
Q_{P P}=0.3 F_{c} \cdot c A_{e}+\frac{s \sigma_{r}}{\sqrt{3}} \cdot s A
$$

${ }_{c} A_{e}:$ 鉄骨パネルに含まれるモルタル断面積

${ }_{s} A$ :鉄骨パネル断面積 ${ }_{s} \sigma_{y}$ :鉄骨ウェプ降伏応力度 (図 16参照)

右辺第 1 項の係数は、パネル内のモルタルが四方をフランジ及びス チフナーで充分に拘束されているため十字形接合部之同等の拘束条 件下にあると仮定し、0.3 とした。実験後の試験体パネルソーンのフ ランジ及びスチフナーには目立った変形が確認されていないため、こ の仮定は妥当であると考えられる。従って、パネルソーンせん断降伏 時の降伏モーメント $\left(M_{P P}\right)$ は、(11)式となる。

$$
M_{P P}=Q_{P P} \times\left(H_{c}-t_{f}\right)
$$

$H c$ :鉄骨柱せい $t ;$ 鉄骨フランジ厚

これより、パネルソーンせん断降伏時の水平荷重 $\left(Q_{M P P}\right)$ は、(12)式とな る(図 15(b)参照)。

$$
Q_{M P P}=\frac{u M_{p p}+I M_{p p}}{h}
$$

${ }_{4} M_{P P,} M_{P P}$ :パネル降伏モーメント(柱頭部, 柱脚部)

パネルソーンのせん断変形による層間変位は以下のように求めた。パ ネルゾーンに作用するせん断力を図 17 に示す。パネルソーンのせん 断変形は、パネル内のモルタルを考慮して以下のように取り扱う。モ ルタルのせん断弾性倸数 $\left(G_{m}\right)$ はせん断ひび割れによって 0.3 程度まで 低下すると仮定している。低隇率を $0 \sim 0.5$ まで変化させたものも図 19 に示した。荷重変形関保に与える影響はそれ程大きくないので、補 強試験体の評価時にはモルタルを無視した。

パネルせん断歪( ケ)は、(13)式となる。

$\gamma=\frac{\tau}{G}=\frac{Q}{G A}=\frac{Q}{G_{s} \cdot s A+G_{m}{ }^{\prime} \cdot A_{e}}$

$Q:$ パネルせん断力

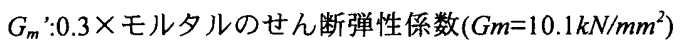

$$
\mathrm{Gm}=E c / 2(1+\nu) \quad \nu: \text { ポアソン比 }(=1 / 6) \text { (文献 8) }
$$

$G_{s}$ :鋼材のせん断弾性係数 $\left(79 \mathrm{kN} / \mathrm{mm}^{2}\right)$

柱頭部と柱脚部のせん断歪を ${ }_{u} \gamma, r$ とすると、パネルせん断変形に よる層間変位 $\left(\delta_{P N}\right)$ は、(14)式となる。

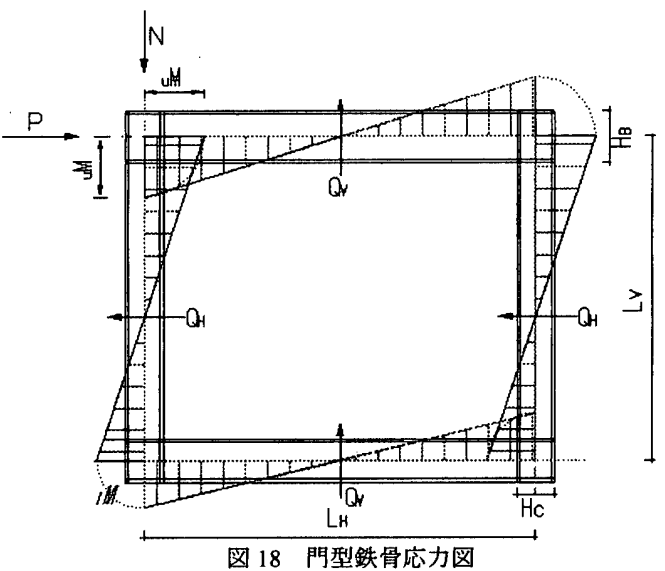


$\delta_{P N}=\frac{{ }_{u} \gamma+, \gamma}{2} \cdot h$

${ }_{u} \gamma$ : せん断歪(柱頭部) ir：せん断歪(柱脚部)

パネルせん断力 $(Q)$ は以下のように求めた。

部材両端の柱全塑性モ一メントとパネルせん断降伏モーメントの 小さいほうによって決まる柱反曲点位置を弾性域の反曲点とすると、 図 18 に示す応力図が得られる。従って、パネルゾーンに作用する応 力は、図 17 に示す通りとなる。ここで、鉄骨ウェブを無視すると、 鉄骨フランジの軸力 $(C, T)$ は、それぞれ(15)式となり、

$$
T_{c}=\left|C_{c}\right|=\frac{M_{c}}{H_{c}-t_{f}}
$$

$M_{c}$ : 柱両端に作用する降伏モーメント

パネルゾーンにせん断力として作用する。ただし、部材せん断力 $\left(Q_{v}\right)$ が $T_{c}$ と逆方向に作用するので、これを差し引きする必要がある。本実 験のような L 字形接合部の場合、 $Q$, の効果を図 17 の様に三角形分布 となると仮定すると、パネルソーンの平均せん断力は、(16)式で表さ れる。

$$
Q=T_{c}-Q_{v} / 2
$$

以上の諸量を用いて得られるNo.2 No.4の終局層せん断力及び変位 の一覧を表 5 に示す。No.2 の荷重変形関係の予測值と実験值の比較を 図 19 に示す。これによると、耐力は概ね安全側に推定している。変 形に関してはやや小さめに推定している。

\begin{tabular}{|c|c|c|c|c|c|}
\hline & \multicolumn{2}{|c|}{ 終局層せん断力 } & \multicolumn{3}{|c|}{ 終局層せん断力時の層間变位 } \\
\hline & $\begin{array}{c}\text { 鉄骨柱全塑性 } \\
\text { モーメント時 } \\
\text { 層せん断力 } \\
\text { (7)式 }\end{array}$ & $\begin{array}{c}\text { パネルせん断 } \\
\text { 降伏時 } \\
\text { 層せん断 カ } \\
\text { (10)式 }\end{array}$ & $\begin{array}{c}\text { 曲げ変形 } \\
\text { による } \\
\text { 層間変位 }\end{array}$ & $\begin{array}{c}\text { パネル } \\
\text { せん断 } \\
\text { 変形による } \\
\text { 層間変位 }\end{array}$ & 全変位 \\
\hline No.2 & 80.9 & 069.1 & 3.11 . & 3.46 & 6.31 \\
\hline No: 3 & 063.0 & 68.2 & 3.66 & 3.98 & 7.26 \\
\hline No.4 & O 39.0 & 71.9 & 3.68 & 2.25 & 5.71 \\
\hline
\end{tabular}

表 5 鉄骨の終局層せん断力及び鉄骨層間変位（No.2 4)

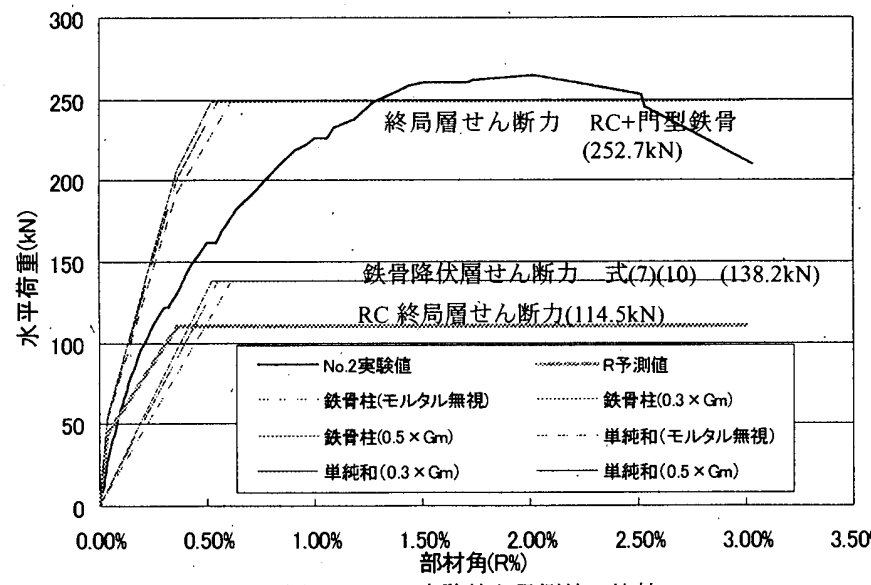

図 19 No.2 実験檤と予測值の比較

\section{3-6 荷重変形関係の実験値と予測値の比較}

図 20 に各試験体の実験値と予測値の比較を示す。

$\mathrm{RC}$ 骨組と門形鉄骨の予測値を単純加算することにより、門形鉄骨で 補強した試験体の終局耐力を安全側で評価している。また、各試験体 の予測終局層せ九断力は、門形鉄骨の降伏開始時の荷重と同等か若干 高い值となっている。

終局層せん断力時の全変位に占めるパネルせん断変形による層間
変位の割合は、40～50\%程度となっている。(表 5 参照) 補強鉄骨を より有効にするためには、パネルソーンの補強が必要であると考えら れる。

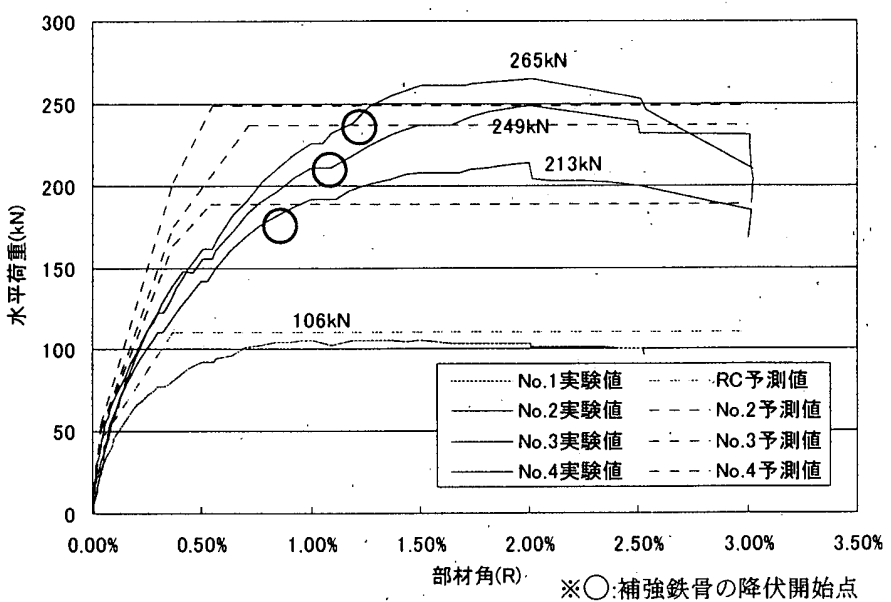

図 20 各試験体の包絡線と計算値の比較

\section{4. 結論}

本研究では、PG 工法の有効性を検証するため、5 6 階建 RC 建物 を想定した 1 層 1 スパンの縮小曲げ降伏形門形 RC 試験体を用いた一 方向繰返し載荷実験を行った。以下に実験の範囲で得られた結論を示 す。

1. 門形鉄骨で補強した No.2 4 は無補強の No.1よりも、絽返し加力 下では安定した挙動を示している。また、No.1 は柱脚部のせん 断破壊により耐力が急激に低下したが、No.2 4 は RC 柱のせん断 破壊後も急激な耐力低下は認められない。

2. No.2 4 を No.1 と比較すると、最大耐力は 2 2.5 倍程度まで向上 しており、充分な強度補強效果を発揮している。

3. RC 骨組と門形鉄骨の予測值を単純加算して求めた耐力は、実験 值を安全側に評価する。

\section{参考文献}

（1）梅宮良之、木下陵二、森田時雄、今井克彦他：鋼管ブレースを使 用した低層 RC. 造建築物の外部補強工法の研究 その 1 5, 日本 建築学会大会学術講演梗概集, C-2 分冊, pp.101-110, 1999.9

（2）久木田真一、萩野谷学、宮川和明、木下陵二、藤澤一善、藤永隆、 大谷泰弘、三谷勲：鋼管ブレースを使用した既存 RC 造建築物の 耐震補強工法に関する実験的研究 その $1 \sim 3$, 本建築学会大会学 術講演梗概集, C-2 分冊, pp.377-382, 2000.9

(3) 宮川和明、久木田真一、萩野谷学、木下陵二、藤澤一善、藤永隆、 井上大輔、大谷泰弘、三谷勲 : 鋼管ブレースを使用した既存 RC 造建築物の耐震補強工法に関する実験的研究 その 4 6, 日本建 築学会大会学術講演梗概集, C-2 分冊, pp.767-772, 2001.9

(4) 折地正博、梖谷榮治他: 既存 RC 構造物の外付鉄骨ブレース工法 による耐震補強に関する実験研究 その $1 \sim 4$, 日本建築学会大会 学術講演梗概集, C-1 分冊, pp.889-896,'1999.9

（5）江崎文也、大久保全陸他 : 出張った柱を有する既存 RC フレーム の外付け鉄骨ブレースによる耐震補強法に関する実験的研究，日 本建築学会構造系論文集，第 529 号, pp.135-142, 2000.3 
（6）藤村勝、毛井崇博他：枠付き鉄骨ブレースによる外付け耐震補強 工法に関する実験的研究、日本建築学会大会学術講演梗概集, C-2 分冊, pp.227-228, 2000.9

（7） 日本建築防災協会:2001 年改訂版 既存鉄筋コンクリート造建築 物の耐震改修指針・同解説, 2001.10

（8）日本建築学会：鉄筋コンクリート構造計算規淮·同解説， 1991.4

（9）日本建築学会 : プレストレストコンクリート設計施工規準・同解 説 1998.11

(10) 日本建築学会 : 鉄筋コンクリート構造計算規準・同解説,付録 20 1971.5

(11) 広沢雅也、後藤哲郎 : 軸力をうける鉄筋コンクリート部材の強度 とねばり, 日本建築学会大会学術講演梗概集, 構造系 pp.817-820,1971.11
(12) 菅野俊介：鉄筋コンクリート部材の復元力特性に関する研究(曲 げ降伏をするはり、柱および無開口耐震壁の強度と剛性に関する 実験的研究)、コンクリートジャーナル Vol.11, No.2 , 1973.2

(13) 日本建築学会 : 鉄骨鉄筋コンクリート構造計算規準・同解説, 1987.6

(14) 西村泰志、南宏一、若林實 : 鉄骨鉄筋コンクリート柱はり接合部 のせん断耐力、日本建築学会構造系論文集第 365 号 pp.87-97、 1986.7

(15) Akihiro SAKAGUCHI, Tadatoshi FURUKAWA, Hisao ENDO, Ryoji KINOSHITA, Kazuaki MIYAGAWA, Masayoshi KURASHIGE, Isao MITANI, Katsuhiko IMAI : Construction of Seismic Retrofitting of University Building by Using CHS Braces and External PC-bars for Shear Reinforcement of R/C Column, fib2002 E-308 ,pp.585-592, 2002 